\title{
"In the Land of Elections, the Populist Man Is King": The Online Communication of Basta and Vox in the 2019 European Elections
}

\section{Celia Belim}

Higher Institute of Social and Political Sciences. University of Lisbon (Portugal)

This article, having an Iberian circumscription, focuses on populist parties -the Portuguese Basta and the Spanish Vox-, specifically on their online communication conducted in the context of the 2019 European elections. Using the mixed method and having a corpus comprised of Facebook posts $(n=40)$ and videos $(n=4)$, a triple content analysis is conducted: quantitative, qualitative, and rhetorical. The results show that, in terms of substance in Facebook, the two political actors, which focalize more on the building of a sense of in-group favoritism -in order to explore the feeling of inclusion, being the posts with this thematic substance the most liked, shared, and commented-, are unequivocal in presenting themselves as representatives of popular sovereignty and do not see conflict in national and European identities. In terms of style, the use of visual image reveals that there are more posts focused on positive emotionality. In the videos, the tone against Europe is more critical and the use of rhetorical diversity is noted, such as emotional bipolarity, Manichaeism, exemplification, use of question mark, regency effect, repetition, factual evidence.

Keywords: Populism, Basta, Vox, online communication, European elections.

\section{W} e cannot deny two things: populism is more widespread than previously assumed (Mair, 2002; Mudde, 2004; Rooduijn, 2013), gaining momentum all around the world (Hameleers and Schmuck, 2017), and "we are also living in digital times" (Ernst et al., 2017: 1), in which social media contribute to the success of populism by providing an inviting environment for both politicians and ordinary citizens to disseminate their political ideas (Hameleers and Schmuck, 2017). 
The ample dissemination of populism is proved by the electoral success of populist parties in the last two decades, but also by the populist message itself that has become more pervasive in Western European public debates (Rooduijn, 2013). Additionally, there is a paucity of research on the specific stylistic and contextual variables that predict populist political communication in a comparative setting.

Engesser et al. (2016: 1123) suggest that further studies on populism should consider social media. Populism continues to gain traction in politics but there has been relatively little research on how it plays out on the Internet (Engesser, Fawzi, and Larsson, 2017: 1).

In this context, this article proposes to study the Iberian populist communication, operated via online, in the context of the 2019 European elections. It is chosen as cases of analysis Iberian political parties / coalitions that have been designated as "populists", as the Portuguese Basta and the Spanish Vox (Sousa, 2019). There are two cases in which popular support has grown: Vox elected three Eurodeputies and is the third Spanish political force (Valdivia, 2019), while the representative of the Basta coalition was elected, in the 2019 Portuguese legislative elections, as a deputy for the Portuguese Parliament.

\section{PEOPLE-CENTRISM: “I LISTEN TO YOU BECAUSE I TALK ABOUT YOU”}

There is a consensus in the literature on the conceptualization of populism as a set of ideas concerning the antagonistic relationship between two constructs: the (good) people and the (evil) elite (e.g., Abts and Rummens, 2007; Hawkins, 2009, 2010; Mudde, 2004, 2007; Pauwels, 2011; Rooduijn and Pauwels, 2011; Stanley, 2008; Taggart, 2000).

Implementing this binary opposition, Albertazzi and McDonnell (2008: 3) explains that populism is an ideology which opposes a graceful and homogeneous people against a set of contemptuous elite and dangerous "other, who are described as depriving or trying to deprive the sovereign people of their natural riches, such as "rights, values, prosperity, identity, and voice". Populism also offers to its followers a sense of solidarity, endowing them of a feeling of belonging and being understood and, then, gives them the strength to mobilize under the flag of a "common identity".

Populism can be conceived in political communication in terms of substance and style. Three main subframes can define the content of populist communication's framework: the focus on ordinary people, anti-elitism, and popular sovereignty that gives power to the people. For example, Mudde (2004: 543) explains that populism is a thin-centered ideology that dichotomizes society into antagonistic groups: the "pure people" versus "the corrupt elite", arguing that politics should be an expression of the general will of the people. Jagers and Walgrave (2007: 322) propose a thin definition of populism as a political communication style of political actors that refers to the people. In this thin conceptualization, populism has no political color and is totally stripped from 
all pejorative and authoritarian connotations. Populist political actors speak permanently about the people. The implicit populist's motto is: "I listen to you because I talk about you" (Jagers and Walgrave, 2007: 323).

There are authors that propose more subframes or key elements to conceptualize "populism". For example, Engesser et al. (2016) sign a 5-key elements proposal: 1) emphasizing the sovereignty of the people; 2) advocating for the people; 3 ) attacking the elites; 4) ostracizing others; and 5) invoking the heartland. The term "heartland" can mean an "imagined community" (Anderson, 1983), the place "in which, in the populist imagination, a virtuous and unified population resides" (Taggart, 2000: 95), the "idealized conception of the community" (Taggart, 2004: 274), "a mythical and constructed sub-set of the whole population" (Mudde, 2004: 546) or, remembering Francis Bacon, the "retrospective utopia" (Priester, 2012: 2 cited in Engesser et al., 2016).

Ernst et al. (2017:3), instead of referring four or five subframes, enunciate three "dimensions" composed of strategies. People-centrism - the first dimensionconsists of four strategies: the populist agent can perform his/her closeness to the people, stress their virtues, praise their achievements, or describe them as a monolithic group. Anti-elitism - second dimension- associates three populist communication strategies: discredit the elite, blame the elite, and detach the elite from the people (Ernst et al., 2017: 6). The restoring sovereignty - the third and last dimension- comprises two strategies: the populist actor demands popular sovereignty by advocating for the people's sovereignty and can also establish a negative and conflictive approach by denying the elite's sovereignty.

Focusing on elements of populist rhetoric employed by both populist politicians and mainstream politicians in televised debates and election posters from the 2014 Romanian European Parliament election campaign, NegreaBusuioc (2016: 45-46), use four dimensions: four dimensions of populist discourse: people-centrism (any reference to the people), criticism of the corrupt political class/ elite (including moral corruption), evoking and acclaiming the greatness of the country, and praise of Christian Orthodox values. The researcher discovers that the feature that defines all populist endeavors in all populist discourses, excepting the Greater Romania Party (PRM), is the people-centric. The mainstream Romanian parties also use populist elements, which "seemed to be a good option in an attempt to maximize electoral success" (Negrea-Busuioc, 2016: 52).

In the electoral context and in populism, the rhetoric, for focusing on communication with persuasive purposes (Aristóteles, 2005: 95-96), plays an outstanding role. Aristotle (2005: 96-97) enunciates three "proofs of persuasion": a) those that reside in the moral character of the issuer, constructing the impression that he is worthy of faith (ethos); $b$ ) those derived from the emotion that the speech arouses in the public (pathos); and $c$ ) those that focus on what the discourse demonstrates (logos).

Using content analysis in opinion articles $(\mathrm{N}=3315)$ of newspapers of five countries (France, Germany, Italy, the Netherlands and the United Kingdom), Rooduijn (2013) explores the argument of the populist message as "mesmerizing". The author demonstrates that public debates in Western European media have 
become more populist over the years, the level of populism is strongly related to the success of populist parties, letters are more populist than other opinion articles and debates in tabloid media are more populist than debates in elite media. Once people-centrism and anti-elitism have become more salient in the debates, citizens are inclined to support those parties that 'own' these populist themes (Rooduijn, 2013: 740).

\section{BEING POPULIST IN ONLINESPHERE AND FACEBOOKSPHERE}

Compared to all media, that establish a connection to the people, social media present the advantage of providing the populist actors with a more direct linkage. Additionally, "the short acerbic nature of populist messages works well in this medium" (Bartlett, 2014: 94).

Some studies preconize that the online media are a favorable stage for the features of populist style. For example, simplification, emotionalization, and negativity, are "perfectly in line with the Internet's attention economy" (Engesser et al., 2017: 8). In parallel, the populist strategies of acquiring power, securing legitimacy, and mobilizing supporters frequently reach non-institutionalizes masses that can be easily found on the Internet. The Internet also permits to populist leaders to use personalized communication channels that allow them to exert their charisma and suggestive power (Engesser et al., 2017: 8) and benefits the populist agents with the cultivation of homophily — the "tendency of similar individuals to form ties with each other" (Colleoni, Rozza, and Arvidsson, 2014: 318).

Empirical evidence, on Italy's populist and non-populist leaders that use Facebook regularly, reveal that populist ideological fragments emerged in Italian leaders' Facebook posts (Mazzoleni and Bracciale, 2018). From this research, it can be inferred that: populism appears to be "endemic" in the Italian facebooksphere; and political agents, even non-populist ones, do not disdain the adoption of typical populist rhetorics (Mazzoleni and Bracciale, 2018).

Schmuck and Hameleers (2019), conducting a quantitative content analysis of Facebook and Twitter posts $(\mathrm{N}=1010)$-made from six weeks before to four weeks after the elections by all 13 leading candidates of each parliamentary party before the 2017 national parliamentary elections in Austria and the Netherlands-, observe that all candidates studied were more likely to make populist statements before than after elections. This practice suggests the use of populist political communication as an instrument of maximizing votes during election season. The findings also suggest that the ideological core of populist political communication, operationalized as the subframes anti-elitism, people-centrism, and popular sovereignty, cooccurs with stylistic elements such as negative emotions, negative and positive tonality, or us-versus-them rhetoric in politicians' self-communication on SNSs. Populist messages have been characterized as highly emotional (Aalberg et al., 2017; Mazzoleni, Stewart, and Horsfield, 2003).

The results of the study conducted by Engesser et al. (2016), that focus on how politicians in four countries (Austria, Switzerland, Italia, and the United 
Kingdom) use Facebook and Twitter for populist purposes, reveal that, by demanding sovereignty to the people, politicians include aspects of democratic theory in their arguments. It is also illustrated that the elites attacked by populists may range substantially, being political, economic, legal, supranational, or media elites. However, there is a pattern associated with the relation between political spectrum and the elite criticized: left-wing politicians tend to criticize preferably the economic elites, while media elites are predominantly criticized by rightwing (Engesser et al., 2016: 1122).

Ernst et al. (2017), in a comparative study evolving six Western democracies, explore the populist communication strategies on Twitter and Facebook employed by a broad spectrum of left-wing, center, and rightwing political actors. Using a semi-automated content analysis of politicians' social media statements $(\mathrm{N}=1400)$, the authors discover that populism is mostly used by political actors at the extremes of the political spectrum (both right-wing and left-wing), by opposition parties, and on Facebook.

Some studies explored the use of an emotional style and of blame attributes by the populist communication. Conducting an experiment using a Dutch sample ( $\mathrm{N}=721)$, Hameleers, Bos, and Vreese (2016) provide insights into the effects of and mechanisms underlying populist blame attribution with regard to the European and national levels of governance. The findings reveal that emotionalized blame attributions influence both blame perceptions and populist attitudes. Identity attachment moderates these effects: emotionalized blame attributions have the strongest effects for citizens with weaker identity attachments. Populist communication that attributes blame to the national government, in order to be effective, needs to use an emotional style. On the other hand, populist communication influences blame perceptions toward the European Union (EU) by simply mentioning or informing that the EU is responsible for generating the heartland's problems. Hameleers, Bos, and Vreese (2016) explain this finding mentioning that EU attitudes may be more volatile and prone to change by informational appointments on responsibility. In opposition, opinions on the national government tend to be more stable, demanding the populist cultivation of negative affect toward the adversaries to change. With the purpose of understanding how the core element of pervasive populist messages —attributing blame- affects the populist attitudes of which citizens, Hameleers and Schmuck (2017) employed a comparative survey experiment in two Western European countries, Austria and the Netherlands $(\mathrm{N}=646)$. The results show that messages blaming the elites or immigrants bolster citizens' populist attitudes, but only for the followers/sympathizers of the message's source. In contrast, for those who opposed the source, populist blame attributions reduce populist attitudes.

Inspired on the literature review, it can be synthetized the elements that characterize the populism (Figure 1). 


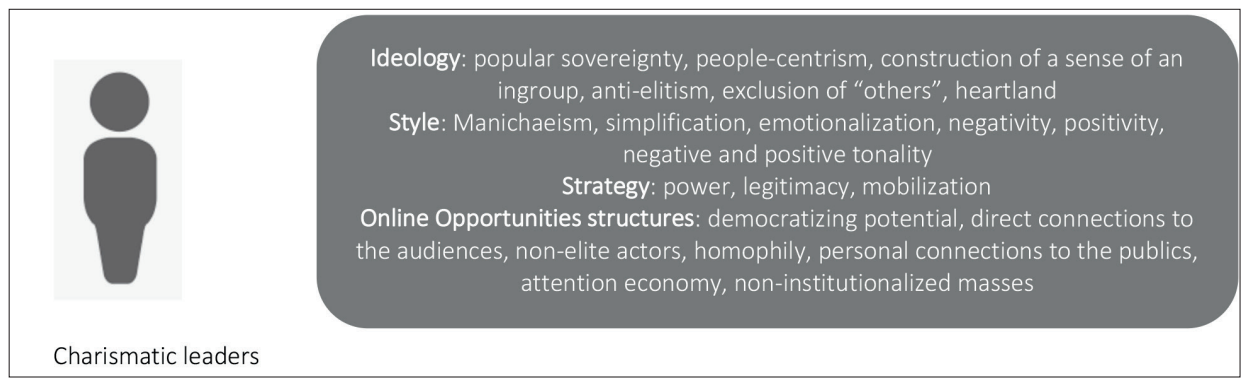

Source: Based on Engesser et al. (2016; 2017: 4); Schmuck and Hameleers (2019).

\section{METHOD AND DATA}

The research question that guides the study is: How do the Iberian political parties / coalitions classified as populist present their online message in the context of the 2019 European elections? Associated with this question, three specific objectives are proposed:

1. To characterize the presence of the populist substance in the Facebook posts of Basta and Vox;

2. To perceive how Basta and Vox present their populist message in Facebook posts -form and rhetoric tactics;

3. To understand the rhetoric tactics used by Basta and Vox in online videos.

The analytical techniques used are: content analysis, qualitative content analysis, and rhetorical analysis.

Content analysis is a research technique for making replicable and valid inferences from texts (or other meaningful messages) to the contexts of their use (Krippendorff, 2004: 18). Remembering the classical Berelson's definition (1952: 18), the content analysis is a research technique for the objective, systematic, and quantitative description of the manifest content of communication. It is used to fulfil the two first aims. A descriptive analysis, including measures of central tendency such as the mean and mode and measures of dispersion such as the standard deviation (SD), is conducted.

The qualitative content analysis is applied in this study with the purpose referred by Zhang and Wildemuth (2009: 309): "goes beyond merely counting words or extracting objective content from text", allowing the understanding of social reality, and considers that "texts act as carriers for ideology" (Koller, 2009). It is, also, used to accomplish the two first objectives and to complement the results derived by the content analysis.

While the discursive framework of populist political communication and its subframes refer to what is expressed in populist political communication (substance), stylistic elements describe how those messages are presented. 
The categories, inspired on literature and used to analyze the messages, are summarized (Table 1).

\section{Table 1. Categories' matrix}

\section{Substance}

Construction of a sense of ingroup favoritism (people-centrism) by framing ordinary people as central to political decision making (Canovan, 1999). The ingroup is therefore framed as the silent majority of everyday citizens (Caiani and Porta, 2011) and, by producing the sense of inclusion, can attract the affinity and identification of people.

Anti-elitism and outgroups: the dichotomy between ordinary people vs. corrupt elites and the other (Albertazzi and McDonnell, 2008); elites stand accused of taking care of themselves only and at the expense of the people, whose will they have been entrusted to protect (Mudde, 2004).

Popular sovereignty: the empowerment of the people while denying the sovereignty of elites, that is, populist political communication recognizes the people as the legitimate sovereign entity and democracy as the mechanism for expressing the vox populi (Canovan, 1999).

Style

Negative emotions: messages impregnated by anger and fear, which are used to intensify the opposition between ordinary people and the disdainful elites (Hameleers, Bos, and Vresse, 2017). Blame attributions are example of stimuli for negative emotions (Hameleers et al., 2016; Hameleers and Schmuck, 2017; Mols and Jetten, 2014).

Positive emotions: such as in-group favoritism, loyalty to the heartland, achievements of hardworking, ordinary citizens (Schmuck and Hameleers, 2019: 5)

Negative tonality: message's overall tone is pejorative (e.g., failure, fiasco, depression, sense of crisis or urgency, culpability to elite or out-groups for negative outcomes) (e.g. Mudde, 2004; Taggart, 2000)

Positive tonality: message's overall tone is optimistic (e.g., achievement, improvement)

Manichaeism, us-versus-them rhetoric: use of the opposition between the ingroup (us, the ordinary people) and the out-groups/elites

Source: Own elaboration.

The social network under analysis is Facebook. It is the largest online social network worldwide, with almost 2.5 billion monthly active users (Clement, 2019) and almost all social media users are on this network (Influencer Marketing Hub, 2019).

The corpus of each party was chosen considering the electoral period (Portugal: May, 13-24; Spain: May, 10-24) and the option "main publications". The application of these criteria resulted in 14 posts by Basta and 26 by Vox.

Rhetorical analysis, a technique more associated with the form of message, is chosen to fulfill the third aim. This type of analysis concentrates on how the message is enunciated instead of what the message enunciates (Neuendorf, 2017: 10). The message is analyzed as an artistically structured instrument for communication and persuasion, involving the breaking the text down into parts. By this procedure, the analyst can understand how the different parts operate, 
providing him/her insights to reconstruct the overall persuasive strategies used. In the conducted analysis, the three "proofs of persuasion" —ethos, pathos, and logos-, enunciated by Aristotle (2005) are considered.

In 2012, 66\% of respondents watched political videos online, and 36\% watched especially political advertisements (Smith and Duggan, 2012). Searches for election-related content on YouTube have grown by nearly four times since presidential candidates have started making their announcements since April 2015 (Stanford, 2016). Since then, people have watched more than 110 million hours of candidate, and issues, related content on YouTube. It is equivalent to 100 times the amount of time it would take to watch all content ever aired on CNN, C-Span, MSNBC, and Fox News combined (Stanford, 2016). Two videos from each party used in the campaign were chosen (Table 2).

Table 2. Corpus

\begin{tabular}{|c|c|c|c|c|}
\hline $\begin{array}{l}\text { Party / } \\
\text { coalition }\end{array}$ & Title of the video & $\begin{array}{l}\text { Views (at } \\
\text { 2020, April 1) }\end{array}$ & Link to access & $\begin{array}{l}\text { Number of } \\
\text { the video }\end{array}$ \\
\hline Basta & $\begin{array}{l}\text { "What is happening across } \\
\text { Europe is a sign of change" } \\
\text { ["O que está a acontecer em } \\
\text { toda a Europa, é um sinal de } \\
\text { mudança"] }\end{array}$ & 1578 & $\begin{array}{l}\text { https://www.youtube.com/ } \\
\text { watch?v=ZMVKPGX5pvQ }\end{array}$ & 1 \\
\hline Basta & $\begin{array}{l}\text { "André Ventura, head of } \\
\text { the BASTA coalition list!" } \\
\text { ["André Ventura, cabeça de } \\
\text { lista da coligação BASTA!"] }\end{array}$ & 1124 & $\begin{array}{l}\text { https://www.youtube. } \\
\text { com/watch?v=ZWFT0pCjP- } \\
\text { s\&list=UU-Wo4qU-W0CNd- } \\
\text { 9Q23GIWKg\&index=69 }\end{array}$ & 2 \\
\hline Vox & $\begin{array}{l}\text { "Frente a la Europa que } \\
\text { reniega de su identidad, } \\
\text { hay una Europa que está } \\
\text { orgullosa de su historia" } \\
\text { ["Faced with the Europe that } \\
\text { denies its identity, there is } \\
\text { a Europe that is proud of its } \\
\text { history"] }\end{array}$ & 30659 & $\begin{array}{l}\text { https://www.youtube.com/ } \\
\text { watch?v=gDGuEFHKhkg }\end{array}$ & 3 \\
\hline Vox & $\begin{array}{l}\text { "La primera medida que Vox } \\
\text { quiere impulsar en Europa es } \\
\text { la reforma de la euroorden" } \\
\text { ["The first measure that Vox } \\
\text { wants to promote in Europe } \\
\text { is the reform of the euro } \\
\text { order"] }\end{array}$ & 1725 & $\begin{array}{l}\text { https://www.youtube.com/ } \\
\text { watch?v=3Dy8hWcbwBM }\end{array}$ & 4 \\
\hline
\end{tabular}




\section{FINDINGS}

Characterizing the Populist Substance of the Facebook Posts OF BASTA AND Vox

Both parties prefer to use the substantive subframe of "construction of a sense of ingroup" (Basta - 12; Vox-17), followed by anti-elitism and popular sovereignty (Table 3).

Table 3. Substantive subframe

\begin{tabular}{l|l|l} 
& Basta & Vox \\
\hline Construction of a sense of ingroup favoritism & 12 & 17 \\
\hline Anti-elitism & 12 & 10 \\
\hline Popular sovereignty & 2 & 5 \\
\hline
\end{tabular}

Source: Own elaboration.

The Basta's posts most liked, shared and commented are the ones related to the construction of a sense of ingroup and anti-elitism (351-400 likes, 176-200 shares, 101-125 comments).

This pattern is also observable among Vox's posts: two posts concentrated on "construction of a sense of ingroup" reach the number of 10001-15000 likes. One post related to popular sovereignty collects 10001-15000 likes. The highest number of likes that a post focusing anti-elitism reaches is 8501-9000. The construction of a sense of ingroup attracts the highest number of shares (75018000), followed by "anti-elitism" (6501-7000) and popular sovereignty (30013500). Construction of a sense of ingroup is the substance most commented (2001-2500), followed by anti-elitism (1501-2000) and popular sovereignty (1001-1500).

It is presented the results of qualitative content analysis that illustrate each of the substantive subframes:

\section{Basta}

1. Ingroup: "the Europe of sovereign nations" (22-05); Vox (24-05); "there is only one candidacy with the courage to speak! (18-05); "André Ventura and the BASTA Coalition" (24-05).

2. Anti-elitism and outgroups: "arriving migrants, who impose their way of life on Europeans, in general conflicting with the way of life, beliefs, religions and traditions of the peoples who host them, globalist movement" (2205); "all-powerful bureaucracy that would rule us under its own pleasure" (22-05); "corrupt and degraded system, never shut us up again" (24-05); "journalists and commentators conciliated with the system" (21-05); "the entertainment" (18-05); "will not be on the "side" of "racists or the extreme right" (21-05). 
3. Popular sovereignty: "we are the popular vote" (21-05); "it may be necessary to defend, unequivocally, the national sovereignty and respect for values of European culture" (22-05).

Vox

1. Ingroup: "today, Rocío Monasterio met with representatives of the rural world to tell them that they will finally have a voice to represent them in the institutions" (22-05); "At Vox we are clear: nobody is going to give us lessons in defense of women. No party presents such harsh measures against aggressors, rapists and murderers" (13-05).

2. Anti-elitism and outgroups: message to the coup-monger Puigdemont: "If he is so brave, let him come to Spain" (11-05); "Coup-mongers have reason to be concerned: Vox will oversee that any concession will be given to coupmongers. We did it in the Supreme Court and, now, we are going to do it in Congress" (21-05); "with politicians, like Errejón, we have nothing to talk about" (15-05); Zapatero's ideological project (22-05); "all the mafias that profit from the illegal trade"; "all the mafias that profit from the illegal trade" (15-05); "politicians who tell us what we need to think or what we have to say" (16-05).

3. Popular sovereignty: "the voice of Spain" (21-05); "Spain is a nation, not a set of nations as some believe" (18-05); "Vox's 24 are already in Congress and with them millions of Spaniards who previously did not feel represented" (17-05).

\section{Form AND RHETORICAL STYLE}

All posts by Basta are composed of text and photo and all posts by Vox are composed of text and video.

Regarding the rhetorical style, the pattern is common to both actors: positive emotions/tonality are the most present, followed by Manichaeism and negativity (Table 4).

Table 4. Style

\begin{tabular}{l|l|l} 
& Basta & Vox \\
\hline Negative emotions/tonality & 9 & 7 \\
\hline Positive emotions/tonality & 13 & 17 \\
\hline Manichaeism & 12 & 14 \\
\hline
\end{tabular}

Source: Own elaboration.

Among Basta's posts, negative and positive emotions are equal in terms of the highest number of likes (351-400), shares (175-200) and comments (101-125) attracted, but two posts on negative emotionality collect the highest number of likes. Manichaeism gathers 351-400 as the highest number of likes, 176-200 of shares and 101-125 of comments. 
In Vox's posts, there are three related to positive emotions that gather likes

between 10001 and 15000. Negative emotions, being less present, attract the highest number of likes (7501-8000). One post using Manichaeism reaches 10001-15000 likes. In comparison to negative emotions, positive emotions reach a higher number of shares (7501-8000 vs. 6501-7000). Manichaeism collects the highest number of shares (7501-8000) and comments (2001-2500). Posts related to positive emotions are more commented than the ones focused on negative emotionality (2001-2500 vs. 1501-2000).

The results of qualitative content analysis explicit the style.

\section{Basta}

1. Negative emotions (pathos): 1 . criticism, concern and "putting the finger on the wound" - "not replacing generations represents not only a slow biological suicide, but, mainly, a cultural suicide" (22-05), "Europe of vast forests is a memory, enduring in Literature, of an unrepeatable time" (22-05), "a complete inversion of values, the absolute sign of impunity and disorder where we live" (17-05), "successive migratory flows" (22-05), "very open borders policy" (22-05), "the unprecedented seriousness of the assumed position of allowing" (22-05), "the EU seems to want to renounce this dignified posture that has always been that of Europe" (22-05); 2. fatalism and fear - "making that same path irreversible, which inevitably will cause us to fall into this common grave of " bankruptcy of everything, because of everyone, bankruptcy of everyone, because of everything" (22-05).

2. Positive emotions (pathos): 1. defense - "defense of our rural space" (2205), "Basta wants to defend the Free Zone in Europe" (22-05); clarification, appeasement: "denounce the climate of fear" (20-05), "Basta Coalition assumes, as its solemn commitment in Brussels, in Strasbourg and where it may be necessary to defend, unequivocally, the national sovereignty and respect for values of European culture" (22-05); 2. pride - "we are very proud of this support" (24-05), "having the support of Christians, of Catholics "for the European elections" is a huge pride" (18-05); "unmasking the system: There are truths that cripple the system" (18-05); 3. courage - "there is only one candidacy with the courage to speak!", "there are many Portuguese who do not doubt who they will vote for! For our values! For the truth!" (18-05); 4. confidence - "we don't stop growing" (21-05); 5. hope and strength - "the wave of hope around Chega continues to increase" (14-05); 6. respect - "respect for freedom, difference and property. Respect for the primacy of Reason and intellectual honesty. Respect for the existence of the two opposite realities that are Truth and Lie. Respect, without any limits, for life in all its phases" (22-05).

3. Manichaeism (logos): "sovereign nation among sovereign nations, free and equal in status and dignity" vs. "European Federation" (22-05); "Rather a police party than the thieves who have ruled us for over 40 years!" (2005); "England, among others, are miserable and scandalously insisting that we end our Free Trade Zone, but they have one of the most aggressive tax havens in the world" (22-05); "We don't stop growing" vs. "They are so 
afraid" (21-05); "Everyone is concerned with destroying those who protect us by passing on a wrong and dangerous image" vs. "André Ventura and the Basta Coalition went to show solidarity with the Police" (24-05).

Vox

1. Positive emotions/tonality (pathos): 1 . determination, confidence and defense of "good causes" - "Vox believes in a legal, ordered and capable of integration immigration" (20-05), "Vox supports traditional businesses, especially Madrid gastronomy that generates thousands of jobs. Vox will reduce administrative and tax rates they support" (17-05), "Vox will effectively pursue all mafias that profit from illegal trade" (15-05), "we are with merchants who fulfill all legal formalities" (15-05); "The voice of Spain: it is already in Congress without fear of anything or anyone" (21-05), "Today, Rocío Monasterio met with representatives of the rural world to tell them that they will finally have a voice to represent them in the institutions" (22-05), "Freedom will return to Madrid with Vox, Vox will end Madrid of fines and prohibitions" (22-05), "we will lead the alternative to the left" (19-05), "because it never needed quotas, because it calls things by name and because it will transform Madrid into a bastion of freedom" (23-05), "safe borders are urgent, all our support for wounded civil guards" (12-05), "Vox had more votes than all the independence parties combined" (11-05), "our 24 deputies will confirm the usefulness of Vox for Spain" (17-05), "we pay attention to the polls. We will be decisive in the community of Madrid" (14-05); 2. exceptionality - "if Javier Ortega did not exist, he would be invented" (10-05).

2. Negative emotions / tonality (pathos): 1. unfairness and revolt - "the campaign is not being the same for everyone. Once again, the electoral council and the interior councilor of the generality allow harassment and violence against Vox" (16-05); 2. frustration - "the Zapatero's ideological project was perpetuated. He imposed all ideological laws on us and found no one ahead" (22-05).

3. Manichaeism/antithesis (logos): others vs. "harassment and violence against" Vox (16-05); "all the mafias that profit from the illegal trade" $v s$. "traders who fulfill all legal formalities" (15-05); "representatives of the rural world" vs. "saloon ecologists and animal defenders who are chatterbox" (22$05)$, "we demand that the illegal ones who assaulted our borders attacking our police officers be expelled immediately" (12-05); "we have very different proposals from other parties" (10-05); "coup-mongers" vs. Vox (21-05); the Spaniards who "entered the EU with effort, work and illusion" vs. "a Europe of sovereign nations" (12-05); "Madrileños dream of maintaining their freedom" vs. "politicians who tell us what we need to think or what we have to say" (16-05); "the Zapatero's ideological project was perpetuated. He imposed all ideological laws on us and found no one ahead" (22-05); "Spain is a nation, not a set of nations as some believe" (18-05). 


\section{INTERACTIVITY}

The interactivity's values of Vox are higher, comparatively to Basta. The mean signifies that, in a hypothetical scenario, if the all posts have the same number of likes it would be, in the case of Basta, 251-300 and, in the case of Vox, 4001-4500. The mode represents the most frequent value (Table 5): in terms of likes, Basta registered mostly the presence of 101-150 and 151-200 by each post repeated three times and Vox 1501-2000; the most frequent number of shares in Basta's publications is 26-50 and in Vox's ones 1-500; 0-25 is the most present number of comments by each Basta's post and 1-500 by each Vox's post. Completing these measures with dispersive ones, the value of standard deviation (SD) is low ( 2 or close) in the case of the three indicators of the interactivity of Basta, indicating that the values tend to be close to the mean. Referring to the Vox's posts, the standard deviation (SD) is 6,063 for likes, 3,840 for shares, and 1,156 for comments.

Table 5. Measures of central tendency

\begin{tabular}{l|l|l|l|l}
\multicolumn{4}{l|l}{} & \multicolumn{2}{l}{ Basta } & Vox \\
\hline Likes & Mean & Mode & Mean & Mode \\
\hline Shares & $251-300$ & $\begin{array}{l}101-150 \text { and 151- } \\
\text { 200 repeated three } \\
\text { times }\end{array}$ & $4001-4500$ & $1501-2000$ \\
\hline Comments & $51-75$ & $26-50$ & $1501-2000$ & $1-500$ \\
\hline
\end{tabular}

Source: Own elaboration.

\section{Rhetoric Tactics Used by Basta and Vox in Online Videos}

In the two videos of Basta, the candidate André Ventura appears exposing the message to the receiver. It is used a medium close-up. One of the Vox's videos adopts the same style. The other uses diverse images.

\section{Basta}

\section{Video 1}

1. Ethos: "able to touch wounds and speak", "you can trust us, because we tell the Portuguese the truth".

2. Pathos:

Positive emotions: confidence - "we are capable", "we want to be that change", telling you, eye to eye, that you can trust us", "it is a problem and we have to have a solution for it"; courage - "touch wounds".

Negative emotions: unfairness, frustration, and revolt - "impunity in justice and shameful cases, such as that of Pedro Dias or Leonor Cipriano", "shame that is this excess of taxes throughout the EU, but especially in 
Portugal", "issue of pedophilia and of the shameful action that Europe has taken in the fight against crime against minors".

3. Logos:

Manichaeism/antithesis: "we want to tell you, eye to eye, that you can trust us, not because we are right, left or center, but because we tell the Portuguese the truth"; "because we are able to touch wounds and to speak" $v s$. who are not able to do this; problems ("impunity in justice and shameful cases", "shame that it is this excess of taxes throughout the EU", "pedophilia and the shameful action that Europe has been taking in the fight against crime against minors") vs. solutions proposal ("chemical castration").

Repetition: "We want", "that's why we have been talking" (3x).

Exemplification: "impunity in justice and shameful cases, such as that of Pedro Dias or Leonor Cipriano"; "excess of taxes across Europe, but especially in Portugal".

Use of question mark and exploration of recency effect: "why do we still not have chemical castration between us?".

\section{Video 2}

1. Ethos: construction of a distinct identity of courage or exceptionality - "The Basta coalition is born with this cry, with this strength, with this determination to say it is enough", "only we have the courage to tell the truth".

2. Pathos:

Negative emotions: unsustainability, frustration and revolt - "political human misery in which we find ourselves", "corruption, influences and misdeeds", "half of our work plan serves to pay taxes, and this is unacceptable. All families, all taxpayers feel in their skin, every day, every month, every year, the effort that this represents", "when we get to the end of the day, we ask what our effort is for, why is what our work is for", "[our work] is for the majority of us to support those who do not want to do anything".

Positive emotions: strength, confidence, and incitement - "the Basta coalition is born with this cry, with this strength, with this determination to say that it arrives", "it is enough"; distinction - "only we have the courage to tell the truth"; confidence - "I trust you and I count on your vote on May 26"; recognition of sovereignty: "the Portuguese go to votes to decide what Europe wants, what future they want for themselves and their families", "I trust you".

3. Logos:

Manichaeism: "it serves us to be mostly supporting those who do not want to do anything at all"; problems (human misery, corruption, influences, half of the salary to pay taxes) vs. solutions (Basta coalition); "the Basta coalition is born with this cry, with this strength, with this determination to say that it is enough of this state of affairs that we have reached" vs. those who don't say it is enough.

Repetition: "it is a fundamental decision", "it is a decision that is up to you and that is fundamental", "enough of", "all families, all taxpayers, every day, every month, every year".

Factuality: "On May 26, the Portuguese will vote". 
Video 3

1. Ethos: "For Spain"

2. Pathos:

Negative emotions: dismay, frustration - "a Europe that has forgotten where it comes from, that denies its history and its roots, a Europe that does not defend itself, that has crisis after crisis, that sells interests and speculators, that blames you for its problems, a paralyzed Europe".

Positive emotions: inspiration, hope - "a Europe that is proud of its history, that knows that the union is born of voluntary cooperation and claims its identity and roots, that is safe for families, a Europe of sovereign and different nations, united by their common heritage, a community that wants to prosper. For this Europe, vote Vox. In Europe for Spain".

3. Logos:

Manichaeism: the description of the present version of Europe $v s$. the promise of a better and inspired Europe: real Europe $v s$. ideal/utopian Europe.

Repetition: "a Europe".

\section{Video 4}

1. Ethos: ability of initiative, proposal of an agenda.

2. Pathos:

Negative emotions: inertia - "they should have seen it because on November 9, 2014, there is a first illegal referendum", "neither the government of the Popular Party nor the Socialist Party did anything to promote the modification of this directive"; insult - "there is something on the electoral list that is absolutely unacceptable, that is a fugitive from justice, for a possible crime of rebellion, a coup d'état against Spain: being on the European election lists is insulting to the nation".

Positive emotions: initiative, perspicacity, show of priorities - "for us, a bleeding theme and one of the first issues that we are going to set in motion", "no party has this issue in its program and, now in the European elections program, all parties put it"; evocation of a greater cause - "explain clearly to Spaniards that they are not voting in our favor", "a matter of common sense, which matters massively to Spaniards".

3. Logos:

Factual evidence: "the euro order system [European arrest and surrender order] came into force on 1 January 2004. From 2004 to 2019, the Popular Party and the Socialist Party will have had 15 years to adjust this", "list of 32 offenses", "should have seen because on November 9, 2014, there is a first illegal referendum [2014 Catalan self-determination referendum]", "in our 100 measures of "España viva", published on October 7, 2018, we would already have the reform of the euro order system". 
Manichaeism: "whoever could have done it is who has the absolute majority in Congress and did not do it" vs. "for us, a bleeding topic and one of the first issues that we are going to set in motion".

Repetition: "bleeding theme".

\section{CONCLUDING DISCUSSION}

The conceptualization of populism is present in the online communication of the Iberian parties analyzed. The two political actors focus on building a sense of ingroup favoritism, seeking to explore the feeling of inclusion. The psychological mechanisms of identification are activated. The ideological social identity is an empirically distinct component of ideological identification (Devine, 2015: 5). The posts of both parties with this thematic substance are the most liked, shared, and commented.

Basta, in the construction of the ingroup, emphasizes "the Europe of sovereign nations", showing the harmonious conciliation between national and European identities, as long as the sovereignty of each European nation is respected. In the construction of this thematic categorization, both parties self-include in it and Basta refers to Vox, revealing the communion of interests.

The frame of the anti-elitism and the other is composed of the utterance of the contemptuous other, such as immigrants, governing politicians, media, racists. Basta, for example, mentions the danger that constitutes "arriving migrants, who impose their way of life on Europeans, in general conflicting with the way of life, beliefs, religions and traditions of the peoples who host them". In an antielitist and nationalist logic, Vox criticizes the "coup-monger" Puigdemont and the pretension of independence of Catalonia from Spain, declaring that "Spain is not a set of nations".

Both actors are unequivocal in presenting themselves as representatives of popular sovereignty: Basta says "we are the popular vote" and Vox that is "the voice of Spain".

In terms of style, parties use assiduously a visual component in their posts, which reveals the recognition of importance attributed to the image, remembering that "a picture is worth a thousand words". The posts adopt simple and short text, fulfilling the attribute of simplification pointed out by Engesser et al. (2017).

Stylistically, the discourse present on Facebook is filled with emotionality (Hameleers et al., 2016). Positivity is more emphasized by both parties, contrary to the theory by Engesser et al. (2017). The use of positivity by both parties reveals a focus on self-praise, confidence, pride, courage, incitement. Positivity can act as an invitation to the recipient to join the ingroup and to hope. Basta makes some notes about Europe ("Europe of vast forests is a memory") but does not adopt a corrosive tone. However, in the study by Hameleers et al. (2016), it is pointed that populist communication influences blame perceptions toward the EU by simply mentioning or informing that the EU is responsible for generating the heartland's problems. 
In the online videos, the Basta's candidate presents himself as "able to touch wounds and speak", exceptional ("only we have the courage to tell the truth") and worthy of the trust (ethos). With this style, he seeks to be credible and, therefore, worthy of vote. Among the positive emotions, the candidate pursues to stimulate confidence and courage, trying to be inspiring. To arouse negative emotions, he mentions "shame that is this excess of taxes throughout the EU, but especially in Portugal" and "issue of pedophilia and of the shameful action that Europe has taken in the fight against crime against minors", criticizing the excess of taxes and inertia and ineffectiveness in solving pedophilia within Europe. Through Manichaeism, he is able to confront ingroup and outgroup more easily. The repetition and the recency effect provoke a better memory of the idea that was repeated or said last. The question mark functions as a phatic element, requiring reflection and an answer from the receiver. Exemplification helps to attribute concreteness to the statement. Anchoring in facts proves the truth of what is said.

In one of the videos, Vox makes a detailed and direct criticism of Europe, saying that it is a "Europe that denies its identity" (pathos). To stimulate positive emotions, it is made a description of what Europe should be. The video emphasizes the purpose of being in Europe: for the Spanish. So, it seems that Europe is a possible way of serving the Spanish's interests. The ethos is more highlighted in the video on the euro order (ability of initiative, proposal of an agenda). In this video, as in all analyzed content, the bipolarity of emotions (pathos), factual evidence, Manichaeism and repetition (logos) are highlighted.

Due to the scarcity of studies on the subject developed in this article, it is proposed, from the point of view of the sender and the message, the analysis of more parties and more digital platforms, including Instagram.

Celia Belim (celiabelim@gmail.com / cbelim@ iscsp.ulisboa.pt) is an assistant professor at the School of Social and Political Sciences, University of Lisbon (ISCSP-U Lisbon), lecturing on Communication Sciences (CC)'s scientific area since 2000. Currently, she is executive coordinator of the graduate degree of the referred scientific area. She has a PhD on CC.
She coordinates projects, such as Communicate health and Agendas and communication. Since 2000, she has participated in several conferences, and publishes in her fields of interest, such as health communication, having published, by invitation from Rowman \& Littlefield Publishers. She has received four academic awards. 


\section{References}

Aalberg, Toril; Esser, Frank; Reinemann, Carsten; Strömbäck, Jesper, and Vreese, Claes H. de (eds.) (2017). Populist Political Communication in Europe. London: Routledge.

Abts, Koen and Rummens, Stefan (2007). "Populism 'versus' Democracy". Political Studies, 55(2), pp. 405-424.

Albertazzi, Daniele and McDonnell, Duncan (2008). "Introduction: The Sceptre and the Spectre". In: Albertazzi, Daniele and McDonnell, Duncan (eds.). Twenty-first Century Populism. NY: Palgrave Macmillan, pp. 1-11.

Anderson, Benedict (1983). Imagined Communities: Reflections on the Origin and Spread of Nationalism. London: Verso.

Aristóteles (2005). Retórica. Lisbon: Imprensa Nacional-Casa da Moeda.

Berelson, Bernard (1952). Content Analysis in Communication Research. Glencoe, IL: Free Press.

Caiani, Manuela and Porta, Donatella della (2011). "The Elitist Populism of the Extreme Right: A Frame Analysis of Extreme Rightwing Discourses in Italy and Germany". Acta Politica, 46(2), pp. 180-202. DOI: <10.1057/ ap.2010.28>.

Canovan, Margaret (1999). "Trust the People! Populism and the Two Faces of Democracy". Political Studies, 47(1), pp. 2-16. DOI: $<10.1111 / 1467-9248.00184>$.

Clement, J. (2019). "Facebook: Number of Monthly Active Users Worldwide 2008-2019". statistica. Available at: <https://www.statista. com/statistics/264810/number-of-monthlyactive-facebook-users-worldwide/. Accessed 3 September 2020>.

Colleoni, Elanor; Rozza, Alessandro, and Arvidsson, Adam (2014). "Echo Chamber or Public Sphere? Predicting Political Orientation and Measuring Political Homophily in Twitter Using Big Data". Journal of Communication, 64(2), pp. 317-332.

Devine, Christopher J. (2015). "Ideological Social Identity: Psychological Attachment to Ideological In-groups As a Political Pheno- menon and a Behavioral Influence". Political Science Faculty Publications, 99.

Engesser, Sven; Ernst, Nicole; Esser, Frank, and Büchel, Florin (2016). "Populism and Social Media: How Politicians Spread a Fragmented Ideology". Information, Communication \& Society, 20(8), pp. 1109-1126. DOI: <10.1080/1 369118x.2016.1207697>.

Engesser, Sven; Fawzi, Nayla, and Larsson, Anders (2017). "Populist Online Communication: Introduction to the Special Issue". Information, Communication \& Society, 20(9), pp. 1279-1292. DOI: <10.1080/1369118x.2017.13 28525>.

Ernst, Nicole; Engesser, Sven; Büchel, Florin; Blassnig, Sina, and Esser, Frank (2017). "Extreme Parties and Populism: An Analysis of Facebook and Twitter Across Six Countries". Information, Communication \& Society, 20(9), pp. 1347-1364. DOI: <10.1080/13 69118x.2017.1329333>.

Hameleers, Michael and Schmuck, Desirée (2017). "It's Us Against Them: A Comparative Experiment on the Effects of Populist Messages Communicated Via Social Media". Information. Communication \& Society, 20(9), pp. 1425-1444. DOI: <10.1080/1369118x.2017.1 328523>.

Hameleers, Michael; Bos, Linda, and Vreese, Claes de (2016). "They Did It": The Effects of Emotionalized Blame Attribution in Populist Communication". Communication Research, 44(6), pp. 870-900. DOI: $<10.1177 / 0093650216644026>$.

Hawkins, Kirk (2009). "Is Chávez Populist? Measuring Populist Discourse in Comparative Perspective". Comparative Political Studies, 42(8), pp. 1040-1067.

-. (2010). Venezuela's Chavismo and Populism in Comparative Perspective. Cambridge: Cambridge University Press.

Influencer Marketing Hub (2019). "50+ Social Media Sites You Need to Know in 2020". Available at: <https://influencermarketinghub. 
com/top-social-media-sites/. Accessed 3 September 2020>.

Jagers, Jan and Walgrave, Stefaan (2007). "Populism As Political Communication Style: An Empirical Study of Political Parties' Discourse in Belgium". European Journal of Political Research, 46(3), pp. 319-345. DOI: <10.1111/ j.1475-6765.2006.00690.x>.

Krippendorff, Klaus (2004). Content Analysis: An Introduction to Its Methodology. Thousand Oaks, CA: Sage.

Koller, Veronika (2009). "Analysing Collective Identity in Discourse: Social Actors and Contexts". Semen. <https://doi.org/10.4000/ semen.8877>.

Mair, Peter (2002). "Populist Democracy vs Party Democracy". In: Mény, Yves and Surel, Yves (eds.). Democracies and the Populist Challenge. NY: Palgrave, pp. 81-98.

Mazzoleni, Gianpetro and Bracciale, Roberta (2018). "Socially Mediated Populism: The Communicative Strategies of Political Leaders on Facebook". Palgrave Communications, 4(1), p. 50. DOI: $<10.1057 / \mathrm{s} 41599-018-0104-\mathrm{X}>$.

Mazzoleni, Gianpetro; Stewart, Julianne, and Horsfield, Bruce (2003). The Media and Neo-populism: A Contemporary Comparative Analysis. Westport, CT: Praeger.

Mols, Frank and Jetten, Jolanda (2014). "No Guts, no Glory: How Framing the Collective Past Paves the Way for Anti-immigrant Sentiments". International Journal of Intercultural Relations, 43, pp. 74-86. DOI: <10. 1016/j.ijintrel.2014.08.014>.

Mudde, Cas (2004). "The Populist Zeitgeist". Government and Opposition, 39(4), pp. 541-563. DOI: $<10.1111 / \mathrm{j} .1477-7053.2004 .00135 . \mathrm{x}>$.

-. (2007). Populist Radical Right Parties in Europe. Cambridge: Cambridge University Press.

Negrea-Busuioc, Elena (2016). "'Of the People or for the People'? An Analysis of Populist Discourse in the 2014 European Parliament Elections in Romania". Romanian Journal of Communication and Public Relations, 18(2), pp. 39-53.
Neuendorf, Kimberly (2017). Content Analysis Guidebook. Thousand Oaks: Sage.

Pauwels, Teun (2011). "Measuring Populism: A Quantitative Text Analysis of Party Literature in Belgium". Journal of Elections, Public Opinion and Parties, 21(1), pp. 97-119.

Rooduijn, Matthijs (2013). "The Mesmerising Message: The Diffusion of Populism in Public Debates in Western European Media". Political Studies, 62(4), pp. 726-744. DOI: $<10.1111 / 1467-9248.12074>$.

Rooduijn, Matthijs and Pauwels, Teun (2011). "Measuring Populism: Comparing Two Methods of Content Analysis". West European Politics, 34(6), pp. 1272-1283.

Schmuck, Desirée and Hameleers, Michael (2019). "Closer to the People: A Comparative Content Analysis of Populist Communication on Social Networking Sites in Pre- and PostElection Periods". Information, Communication \& Society, 23(10), pp. 1-18. DOI: $<10.1080$ /1369118x.2019.1588909>.

Smith, Aaron and Duggan, Maeve (2012). "Online Political Videos and Campaign 2012". Pew Research Center. Available at: <https:// www.pewresearch.org/internet/2012/11/02/ online-political-videos-and-campaign-2012/>. Accessed 3 September 2020.

Sousa, R. Pedro (2019). "Que história é essa do populismo?". Observador. Available at: $<$ https://observador.pt/opiniao/que-historiae-essa-do-populismo/>. Accessed 3 September 2020.

Stanford, Kate (2016). "How Political Ads and Video Content Influence Voter Opinion". Think with Google. Available at: <https://www. thinkwithgoogle.com/marketing-resources/ content-marketing/political-ads-video-content-influence-voter-opinion/>. Accessed 3 September 2020.

Stanley, Ben (2008). "The Thin Ideology of Populism". Journal of Political Ideologies, 13(1), pp. 95-110.

Taggart, Paul (2000). Populism. Buckingham; Philadelphia: Open University Press. 
—. (2004). "Populism and Representative Politics in Contemporary Europe". Journal of Political Ideologies, 9(3), pp. 269-288.

Valdivia, Ana (2019). "Far-right Party Vox Becomes the Third Political Force in Spain After Second Election". Forbes. Available at: $<$ https://www.forbes.com/sites/anagarciavaldivia/2019/11/12/far-right-vox-becomes-thethird-political-force-in-spain-after-second- election/\#59ddfe467f85>. Accessed 3 September 2020 .

Zhang, Yan and Wildemuth, Barbara M. (2009). "Qualitative Analysis of Content". In: Wildemuth, Barbara (ed.). Applications of Social Research Methods to Questions in Information and Library Science. Santa Barbara: Greenwood Press, pp. 308-319. 